\title{
MENGEMBANGKAN KERJASAMA (SOFT SKILL) MELALUI PENERAPAN METODA COOPERATIF LEARNING DAN EXPERIENTIAL LEARNING DALAM MATA KULIAH PSIKOLOGI KEWIRAUSAHAAN
}

\author{
Lala Septiani $\mathbf{S}^{1}$, Yantri Maputra ${ }^{2}$
}

\begin{abstract}
This research aimed to examine the effect of the value of student co-operation in enterpreneur courses through the implementation of co-operative learning and experiential teaching method. Research was conducted on 57 psychology students who take enterpreneur courses treated in method cooperative teaching and experiential learning. Data collected through the scale were analyzed using the $t$ test to see differences in the ability of co-operation between the students before teaching method experiential learning and cooperative learning with teaching method after doing experiential learning and cooperative learning. $T$ test results prove that there are significant differences between the data pre and post data. This study means that there is a significant difference in the value of co-operation caused by the treatment by student cooperative learning and experiential learning method.
\end{abstract}

Keywords: Psychology students, Enterpreneur Courses, co-operative learning and experiential teaching method.

\section{A. PENDAHULUAN}

\section{Latar Belakang}

T ugas pokok pengembangan sumber daya manusia adalah untuk menga rahkan mahasiswa memiliki kemam puan hard skill dan soft skill. Hard skill bertujuan untuk membantu seseorang dalam memperoleh pekerjaan, sedang soft skill lebih spesifik untuk membantu seseorang tersebut dalam mendapatkan karir kerja yang baik. Dapat dipastikan bahawa semua orang tidak hanya berhenti dengan mendapatkan perkerjaan semata, dengan pekerjaan itu dia ingin mendapatkan posisi yang baik untuk mengembangkan karirnya pada tingkat yang lebih tinggi. Sering kali mahasiswa setelah terjun pada dunia kerja mendapatkan kendala untuk mengembangkan karirnya, hal ini dise babkan salah satunya adalah karena mahasiswa tersebut hanya memiliki kemampuan kerjasama sebagai bagian dari kemampuan soft skill. Soft skill adalah kopetensi yang dibutuhkan dalam dunia kerja seperti yang dikatakan oleh (Widarto : 2009). Dunia kerja atau dunia industri membeutuhkan kopetensi seperti kerja sama, kreativitas, disiplin, kejujuran, komitmen, tanggungjawab, rasa percaya diri, etika, sopan santun, komunikasi, kepemimpinan, enterpreneurship dan organisasi.

Kepentingan kerjasama sebagai bagian dari kemampuan soft skill dalam dunia kerja di ungkapkan oleh survey yang dilakukan oleh Mitsubishi Research Institute (dalam Endrotomo, 2010) yang melakukan survey tentang faktor yang memberi kontribusi keberhasilan dalam dunia kerja. Hasil survey tersebut memberikan gambaran bahwa aspek finansial 10\%, keahlian bidangnya 20\%, networking $30 \%$ dan soft skills $40 \%$. Makna yang sama juga dilakukan penelitian oleh Goleman (1995) yang membuktikan bahwa faktor kesuk sesan sesorang hanya $20 \%$ oleh

\footnotetext{
${ }^{1}$ Penulis adalah Dosen tetap Program Studi Psikologi Fakultas Kedokteran Universitas Andalas

${ }^{2}$ Penulis adalah Dosen tetap Program Studi Psikologi Fakultas Kedokteran Universitas Andalas
} 
kecerdasan intelektualnya (IQ) dan 80\% merupakan bagian dari faktor pendukung lainnya, termasuk kecerdasan emosi.

Kalau berbicara terhadap kepentingan kerjasama dalam dunia kerja Pattanayak (2002) mengatakan bahwa faktor yang dapat mempengaruhi semangat kerja karyawan, yaitu: a) perasaan kebersamaan; b) kejelasan tujuan atau objektif yang diraih; c) pengharapan keberhasilan terhadap tujuan yang diinginkan; d) rasa kerja sama dalam melaksanakan tugas demi tercapainya tujuan; e) memiliki pemimpin yang memberikan dukungan dan dorongan. Pernyataan ini bermakna bahwa faktor yang mempengaruhi semangat kerja karyawan adalah adanya perasaan kebersamaan, yaitu rasa saling memiliki dan peduli antar anggota kelompok kerja dan rasa kerja sama dalam memberikan dukungan dan dorongan, yaitu tugas yang diberikan akan dilaksanakan dengan saling berpartisipasi antar anggota kelompok kerja. Perasaan kebersamaan dan rasa kerja sama dalam melaksanakan tugas merupakan bagian dari kohesivitas kelompok kerja, sehingga dapat dikatakan bahwa yang mempengaruhi semangat kerja karyawan adalah kohesivitas kelompok kerja.

Kalau diperhatikan dengan seksama bahwa rasio kebutuhan soft skills dan hard skills di dunia kerja berbanding terbalik dengan pengembangan soft skills di perguruan tinggi, yang membawa dan mempertahankan orang di dalam sebuah kesuksesan $80 \%$ soft skills dan $20 \%$ hard skills namun di perguruan tinggi atau sistem pendidikan kita saat ini soft skills hanya diberikan rata-rata $10 \%$ dalam kurikulumnya (Illah Sailah, 2007).

Fenomena yang menarik kita temui bahwa dalam kehidupan nyata sehari-hari nilai kerjasama ini ternyata belum sepenuhnya menjadi modalitas kebiasaan di antara para mahasiswa dalam mencapai sukses dalam belajar. Nilai kerjasama ini ternyata masih harus dikembangkan di kalangan mahasiswa. Hal ini didukung oleh penelitian yang dilakukan oleh Harun Rasyid \& Asrori (2006) telah melaporkan hasil penelitiannya di Universitas Tanjungpura, bahwa aspek-aspek penunjuk kerjasama dalam kerja tim semuanya masuk kategori rendah (berkisar antara 30-32\%), kecuali hanya aspek bekerjasama yang masuk dalam kategori sedang (38,04\%), mereka berkesimpulan bahwamasalah kemampuan bekerjasama perlu diintervensi secara serius kepada mahasiswa. Hal ini juga dapat kita lihat dari penuturan beberapa orang mahasiswa yang menjadi pengurus organisasi mahasiswa, mereka mengatakan bahwa setiap akan mengadakan kegiatan yang menjadi kendala mereka adalah kerjasama dalam kalangan kepenitiaan yang mereka bentuk.

Maka dari itu istititusi yang melahirkan suber daya tersebut di harapkan melakukan usaha pengembangan kerja sama sebagai bagian dari soft skill di samping memacu pengembangan hard skillnya. Salah satu usaha adalah mengarah kepada seperangkat kurikulum yang mampu mengintegrasikan nilai kerjasama ke dalam proses pembelajaran. Pengembangan soft skils dapat dilakukan melalui proses pembelajaran (intrakurikuler) dan kegiatan kemahasiswaan (ekstrakurikuler). Pengem bangan soft skils melalui kegiatan belajar atau tatap muka di dalam kelas memerlukan kreativitas dosen pengampu mata kuliah dengan tetap pada pencapaian kompetensi mata kuliah tersebut. Pengembangan soft skils melalui kurikulum dapat ditempuh dengan dua cara. Pertama, melalui kegiatan pembelajaran yang secara eksplisit diintegrasikan dalam mata kuliah yang dituangkan dalam RKPS. Kedua, dapat dilakukan melalui proses hidden kurrikulum, yaitu suatu strategi pengembangan soft skils yang disampaikan oleh dosen kepada mahasiswa secara terintegrasi pada saat perkuliahan berlangsung. Biasanya cara kedua ini dilakukan dosen melalui panutan (contoh atau teladan), dan juga melalui pesan-pesan selingan pada saat pelaksanaan perkuliahan. Upaya pengem bangan soft skils melalui pesan-pesan selingan dapat menggunakan kata-kata mutiara, lagu-lagu, peribahasa, cerita, film (video clip), yang memotivasi dan inspiratif, dan tidak kalah penting adalah peran pimpinan (dosen) sebagai role model (Sriartha dan Sudiana, 2009). Pembinaan nilai kerjasama di kalangan mahasiswa dapat diintervensi melalui pola pembelajaran yang memungkinkan tumbuh-kembangnya 
nilai itu dan membentuk solidaritas sosial yang menunjang keberhasilan diantara mereka.

Berdasarkan kepentingan kerja sama dan fenomena yang ditemui di kalangan mahasiswa tersebut peneliti merasa perlu melakukan penerapan nilai kerjasama dalam pengajaran.

\section{Rumusan Masalah}

A dakah perbedaan kerjasama mahasiswa sebelum dan sesudah pembelajaran kooperatif learning?

\section{Tujuan Penelitian}

$\mathrm{T}$ ujuan penelitian ini adalah untuk mengetahui apakah ada perbedaan yang signifikan kerjasama mahasiswa antara sebelum dan sesudah pelaksaan motede pembelajaran kooperatif

\section{Manfaat Penelitian}

\subsection{Manfaat Teoritis}

$\mathrm{P}$ enelitian ini juga diharapkan dapat memperkaya sumber kepustakaan di bidang pengembangan sumberdaya manusia khususnya mengenai kerjasama dalam tim.

\subsection{Manfaat Praktis}

a. Bagi subjek penelitian, penelitian ini diharapkan dapat memberikan informasi mengenai kerjasama dalam tim.

b. Bagi Pendidik, penelitian ini diharapkan sebagai informasi yang menjadi dasar pembentukan nilai kerjasama dalam pengajaran di perguruan tinggi

\section{B. TINJAUAN KEPUSTAKAAN}

\subsection{Pengertian Kerjasama}

K

erjasama atau Task Cohesion Forsyth (2010) adalah merupakan kemampuan anggota untuk dapat menghasilkan kinerja yang sukses sebagai unit yang terkoordinasi dan sebagai bagian dari kelompok. Komponen ini terdiri atas dua indikator, yaitu teamwork dan collective efficacy. Teamwork atau kerjasama merupakan kombinasi aktivitas dari dua atau lebih individu yang mengkoordinasikan usaha mereka untuk membuat sesuatu. Collective effcicacy atau efikasi kolektif merupakan kepercayaan bersama bahwa suatu kelompok mampu mengorganisir dan melakukan tindakan untuk mencapai tujuan dan menyelesaikan tugas.

Huzzo, R. A. (1995) lebih lanjut menerangkan bahwa adanya kerjasama (teamwork) dapat menimbulkan kohesivitas antar anggota kelompok, Individu yang bekerjasama untuk menyelesaikan tugastugas mereka bersama demi tercapainya tujuan kolektif kelompok. Hal ini membuat individu dalam suatu kelompok memiliki tanggung jawab yang sama besarnya akan hasil yang dicapai. Kerjasama adalah satu usaha antara orang perorang atau kelompok manusia untuk mencapai usaha bersama (Sukanto 2000). Baron \& Byane 2000) satu usaha atau bekerja untuk mencapai hasil bersama.

\subsection{Motode Cooperatif Learning}

Menurut Johnson dalam B. Santoso (1999) Cooperative Learning adalah kegiatan belajar mengajar yang dilakukan oleh guru dalam bentuk kelompok-kelompok kecil, siswa belajar dan bekerjasama untuk sampai pada pengalaman belajar yang optimal, baik pengalaman individu maupun kelompoknya. Untuk pemahaman lebih lanjut tentang motode pengajaran kooperatif ini dapat dilihat dalam karakteristik pembelajaran kooperatif berikut ini.

Karakteristik pembelajaran kooperatif diantaranya:

a. Siswa bekerja dalam kelompok kooperatif untuk menguasai materi akademis.

b. Anggota-anggota dalam kelompok diatur terdiri dari siswa yang berkemampuan rendah, sedang, dan tinggi.

c. Jika memungkinkan, masing-masing anggota kelompok kooperatif 
berbeda suku, budaya, dan jenis kelamin.

d. Sistem penghargaan yang berorientasi kepada kelompok daripada individu.

\subsection{Motode Ekperiensial Learning}

Experiential learning didefinisikan sebagai "the process whereby knowledge is created through the transformation of experience. Knowledge results from the combination of grasping and transforming experience"(Kolb, 1984). Experiential learning menekankan pada kapasitas manusia untuk merekonstruksi pengalaman dan kemudian memaknainya (Savin, 2004:31). David Kolb (1984) menyampaikan model proses Experiential learning yang berupa proses yang melingkar dan terdiri dari empat fase. Fase Concrete Experience menggunakan pengalaman yang sudah dilalui peserta atau pengalaman yang disediakan untuk pembelajaran yang lebih lanjut. Fase Reflective Observation mendiskusikan pengalaman para peserta yang telah dilalui atau saling berbagi reaksi dan observasi yang telah dilalui. Fase Abstract Conceptualization proses menemukan tren yang umum dan kebenaran dalam pengalamanyang telah dilalui peserta atau membentuk reaksi pada pengalaman yang baru menjadi sebuah kesimpulan atau konsep yang baru. Fase Active Experimentation modifikasi perilaku lama dan mempraktikkan pada situasi keseharian para peserta. Untuk pemahaman lebih lanjut tentang motode pengajaran kooperatif ini dapat dilihat dalam karakteristik pembelajaran Experiential learning.

Krakteristik metode pengajaran Experiential learning di antaranya:

a. Para pembelajar belajar yang terbaik adalah ketika mereka dilibatkan dalam pengalamanpengalaman pembelajaran.

b. Ide dan prinsip yang dialami dan ditemukan oleh pembelajar akan lebih efektif dalam perubahan perilaku.

c. Terdapat perbedaan gaya pembelajaran yang disukai dari masing-masing individu.Komitmen para pembelajar dalam belajar akan lebih besar bila mereka turut terlibat pada proses pembelajaran mereka sendiri.

d. Pembelajaran terjadi melalui proses pengalaman yang kongkret (concrete experience), observasi reflektif (reflective observation), konseptualisasi abstrak (abstract conceptualisation) dan eksperimentasi aktif (active experimentation).

e. Perilaku pembelajaran akan mempengaruhi keyakinan seseorang. ( $\mathrm{Ng}, 1997)$

\section{METODE PENELITIAN}

\subsection{Jenis dan Desain Penelitian 3.1.1.Jenis Penelitian}

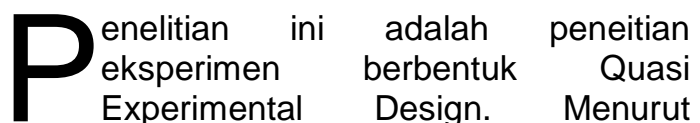
Sugiyono (2006 ), bentuk quasi eksperimen adalah bahwa desain ini mempunyai kelompok kontrol, tetapi tidak dapat berfungsi sepenuhnya untuk mengontrol variabel-variabel luar yang mempengaruhi pelaksanaan eksperimen. Quasi Experimental Designdi gunakan karena pada kenyataannya sulit mendapatkan kelompok kontrol yang digunakan untuk penelitian

\subsubsection{Desain Penelitian}

A dapun desain yang digunakan dalam penelitian eksperimen. Penelitian eksperimen ialah merupakan penelitian yang dilakukan secara sengaja oleh peneliti dengan cara memberikan treatment/perlakuan tertentu terhadap subjek penelitian guna membangkitkan sesuatu kejadian/keadaan yang akan diteliti bagaimana akibatnya. Dalam penelitian ekspreimen ini dilakukan tiga langkahlangkah sebagai berikut:

1. Mengukur variabel terikat sebelum treatment atau perlakuan dilakukan. 
2. Memberikan treatment atau perlakuan kepada subjek yaitu metode eksperimen (percobaan) pada kelompok eksperimen

3. Memberikan posttest untuk mengukur variabel terikat setelah perlakuan

\subsubsection{Definisi operasional}

erjasama atau Task Cohesion Forsyth (2010) adalah merupakan kemampuan anggota untuk dapat menghasilkan kinerja yang sukses sebagai unit yang terkoordinasi dan sebagai bagian dari kelompok

\subsubsection{Persiapan Alat ukur}

Persiapan alat ukur melalui beberapa tahap, yaitu

a. Adaptasi alat ukur, yang meliputi penerjemahan alat ukur, melakukan uji keterbacaan alat ukur, dan profesonal judgement

b. Ujicoba alat ukur

c. Melakukan uji statistik terhadap hasil ujicoba alat ukur, berupa uji reliabilitas, validitas, ada daya beda aitem.

d. Melakukan perubahan alat ukur sesuai dengan hasil statistik

\subsection{Lokasi penelitian}

Penelitian ini akan dilakukan pada mahasiswa program studi Psikologi.

\section{3..3 Alat ukur}

Penelitian ini akan menggunakan dua alat ukur yang mengukur kerjasama Forsyth (2010) bagian dari kohesivitas .

\subsection{Rancangan penelitian}

Penelitian dengan pendekatan kuantitatif menggunakan alat ukur yang sesuai dengan variabel yang diteliti dan kemudian menghasilkan data statistik. Kuesioner merupakan salah satu bentuk alat ukur yang digunakan dalam penelitian kuantitatif. Kuesioner adalah alat ukur yang berisi serangkaian pertanyaan yang dibaca sendiri oleh responden dan responden menjawab pertanyaan tersebut sesuai dengan pemahamannya (Kumar, 1996).

\subsubsection{Teknik pengumpulan data}

Desain teknik pemilihan responden untuk penelitian ini adalah untuk angkatan 2011

\subsection{Jumlah sampel}

Penelitian ini akan dilakukan terhadap mahasiswa program studi psikologi angkatan 2011.

\subsection{Analisis data}

Analisis data statistik dilakukan dengan menggunakan SPSS 12.0. Analisa yang digunakan berupa statistik deskriptif untuk menjelaskan tentang data demografis responden, ujian $t$ untuk melihat perbedaan antara ujian pra dengan ujian post.

\section{HASIL PENELITIAN}

$P$ engukuran tentang kemampuan soft skill mahasiswa dalam metode pengajaran experiential learning dan cooperatif learning dilakukan dengan ujian pra dan uji post untuk nilai kerja sama. Sedangkan pengukuran untuk nilai kreativitas dilakukan dengan pendekatan objektivitas. Data yang dikumpulkan melalui skala untuk nilai kerjasama dianalisis dengan mengunakan uji $t$ untuk melihat perbedaan kemampuan kerjasama mahasiswa antara sebelum dilakukan metede pengajaran experiential learning dan cooperatif learning dengan sesudah dilakukan metede pengajaran experiential learning dan cooperatif learning. Hasil uji t membuktikan bahwa terdapat perbedaan yang signifikan antara data pra dan data post.. Hasil ujian $t$ dapat dilihat dalam tabel berikut.

\begin{tabular}{llllll}
\hline No & Variabel & $\mathrm{N}$ & Mean & Nilai t & Sig \\
\hline 1 & Kerjasama post & 52 & 3.7324 & \multirow{2}{*}{18.931} & \multirow{2}{*}{000} \\
2 & Kerjasama pra & 52 & 2.9218 & \\
\hline
\end{tabular}


Tabel hasil uji t di atas bermakna bahwa nilai kerjasama dapat ditingkatkan melalui pengajaran. Jewell dan Siegel (1990) mendefinisikan kerjasama sebagai tingkat sejauh mana anggota kelompok saling tertarik satu sama lain dan merasa menjadi bagian dari kelompok tersebut (dalam Dwityanto, 2012). Robbins (2012) juga menyatakan bahwa kerjasama merupakan tingkat dimana para anggota kelompok saling tertarik satu sama lain dan termotivasi untuk tetap tinggal di dalam kelompok. Dalam pengajaran kooperatif yang dilakukan dalam bentuk penugasan ini siswa di berikan berupa penugasan untuk membuat sebuah proyek wirausaha. Proyek wirausaha ini dimulai dari pembuatan proposal, perancanaan bisnis sampai aplikasi pemasaran produk yang dibuat pada konsumen. Ketertarikan untuk menyelesaikan tugasan secara bersama ini yang membuat mahasiswa dapat bekerjasama, kerana mahasiswa saling terikat oleh misis menyelesai tugasan tersebut. Ikatan hubungan yang kuat adalah modal untuk bekerjasama sepeti yang disampaikan oleh Forsyth (2010) menyimpulkan bahwa kohesivitas kelompok merupakan suatu kekuatan ikatan yang menghubungkan anggota dengan kelompoknya. Kohesivitas menjadi indikasi dari kesehatan kelompok dan berkaitan dengan beragam proses kelompok lainnya.

Hasil yang signifikan melalui uji $t$ diatas juga diperkuat oleh perbedaan mean antara item kerjasama data yang dikumpulkan sebelum perlakukan metode pengajaran dengan data yang dikumpulkan sesudah dilakukan pengajaran. Data perbedaan mean tersebut menunjukkan bahwa terdapat sebanyak empat item nilai kerjasama yang memiliki mean diatas empat untuk uji pra. Sedangkan untuk uji post terjadi peningkat yang tinggi untuk item nilai kerjasama yaitu terdapat sebanyak 12 item yang memiliki mean di atas empat.

Tabel 1.2 Deskriptif Min Item Berjasama Sebelum Dilakukan Experiential Learning Dan Cooperatif Learning

\begin{tabular}{lll}
\hline NO & Item & Nilai Mean \\
\hline 1 & Percaya terhadap kemampuan anggota lain dalam menyelesaikan & 4.09 \\
& tugas & 4.28 \\
2 & Bekerja sebaik mungkin untuk mencapai tujuan & 4.00 \\
3 & Bangga dengan hasil kerja kelompok & 4.01 \\
4 & Memamfaatkan jam istirahat untuk menyelesaikan tugas kelompok & \\
\hline
\end{tabular}

Tabel 1.3 Deskriptif Mean Item Kerjasama Sesudah Dilakukan Experiential Learning Dan Cooperatif Learning

\begin{tabular}{lll}
\hline NO & Item & Nilai Min \\
\hline 1 & Bekerja sebaik mungkin untuk mencapai tujuan & 4.31 \\
2 & Salin membantu dalam menyelasaikan tugas & 4.28 \\
3 & Saling menyapa antara anggota kelompok & 4.16 \\
4 & Cepat dalam melaksanakan tugas & 4.00 \\
5 & Perlakuan yang baik bagi semua anggota kelompok & 4.00 \\
6 & Bekerja sama dalam dalam menyelesaikan tugas yang sulit & 4.10 \\
7 & Saling membantu bila dapat masalah dalam menyelasikan tugas & 4.31 \\
8 & Bekerjasama membuat mereka mudah menambah relasi & 4.12 \\
9 & Bekerjasama menjadikan mereka menambah pengalaman baru & 4.17 \\
10 & Tangung jawab dalam tugas bersama & 4.07 \\
11 & Bangga dengan hasil kerja kelompok & 4.03 \\
12 & Bekerjasama membuat mereka belajar untuk menjadi lebih baik & 4.02 \\
\hline
\end{tabular}

Dua tabel perbedaan mean tersebut
dapat memberikan makna bahwa
kemampuan kerjasama mahasiswa
mengalami perkembangan yang cukup

berarti setelah dilakukan metode pengajaran cooperatif learning. Perbe daan kemampuan kerjasama tersebut dapat dilihat dari kemampuan kerjasama yaitu bekerja sebaik 
mungkin untuk mencapai tujuan, saling membantu dalam menyelasaikan tugas, saling menyapa antara anggota kelompok, cepat dalam melaksanakan tugas, perlakuan yang baik bagi semua anggota kelompok, bekerja sama dalam dalam menyelesaikan tugas yang sulit, saling membantu bila dapat masalah dalam menyelasikan tugas, bekerjasama membuat mereka mudah menambah relasi, bekerjasama menja dikan mereka menambah pengalaman baru, tangung jawab dalam tugas bersama, bangga dengan hasil kerja kelompok, bekerjasama membuat mereka belajar untuk menjadi lebih baik.

\section{E. Kesimpulan}

$\mathrm{M}$ etode kooperatif dan experiential learning bukan merupakan barang baru dalam dunia pendidikan, pertama kali dipekenalkan pada tahun 1984 oleh David A. Kolb dengan berbagai prinsipprinsip pembelajaran yang memungkinkan para peneliti maupun praktisi pembelajaran di masa sekarang untuk menenerapkan dalam mengem bangkan kemampuan soft skill mahasiswa. Model ini dapat digunakan terutama dalam meningkatkan kerjasama dalam kalangan mahasiswa dalam menyelesaikan suatu tugas yang yang diberikan. Melalui model kooperatif siswa dalam bertikar informasi dalam kelompoknya dan kemudian mereka juga sangat memungkinkan untuk mengeksplorasi pengalaman masa lalunya untuk dijadikan sumber pengetahuan bagi orang lain dan dirinya sendiri untuk kemudian diolah menjadi pengetahuan baru dalam menyelesaikan tugasnya melalaui experiential learning.

\section{Daftar Pustaka}

Baron \& Byane, Social psychology, ninth edition, Pinted in the United State Americ

B Santos, Cooperative Learning: Penerapan Tekhnik Jigsaw Dalam Pembelajaran Bahasa Indonesia di SLTP. Buletin Pelangi

Dedi Supriadi.1994. Kreativitas, Kebudayaan \& Perkembangan Iptek. Alfabeta: Bandung.

Dwityanto, A., Amalia, P. A. 2012. Hubungan antara Kohesivitas Kelompok dengan Komitmen Organisasi pada Karyawan. Prosiding Seminar Nasional Psikologi Islami hal 270-276.

Forsyth, D. R. Group Dynamic Fifth Edition. Belmont: Wadsworth, Cengage Learning.

Kolb, A.D. (1984). Experiential Learning, Experience as The Source of Learning and Development. New Jersey: Prentice Hall, Inc., Englewood Cliffs.

Kolb, Alice Y \& David A.Kolb.2008. Experiential Learning Theory : A Dynamic, Kolistic Approach to Management Learning, Education and Developmental . 2008. Department Of Organizatonal Behavior Weatherhead School of Management

Mohtar, Lilia Ellany.2012. Ciri- Ciri Kreativiti Bakal Guru Fizik Dalam Latihan Amali Fizik dan Projek Inovasi Fizik. Disertasi Sarjana: Universiti Teknologi Malaysia

Mastuki. Kualitas Lulusan Perguruan Tinggi dan Akseptabilitas STAKEHOLDER, 2 Desember 2013. Melalui http://www.diktis.kemenag.go.id diunduh pada tanggal 6 November 2014

Savin, M., Baden \& Major, C.H. (2004). Foundation of Problem - Based Learning. Maidenhead: Open University Press/SRHE

Soekanto 2002, Sosiologi sauatu pengantar, Jakarta PT Jasa Grapinda Persada

Sugiyono.(2006). Metode Penelitian Bisnis. Salemba Empat, Jakarta

Sugandi, A.I.2002. Pembelajaran Pemecahan Masala Matmatika Melalui Model Belajar Kooperatif Tope Jigsaw. (Studi Eksperimen terhadap Siswa Kelas Satu SMU Negeri di Tasikmalaya). Tesis PPS UPI: Tidak diterbitkan.

Nurhadi dkk 2004. Pembelajaran Kontektual dan Penerapan KBK. UM Press: Malang. 
Widarto, Pardjono dan Noto Widodo. 2009. Pengembangan model pembelajaran soft skills dan hard skills untuk siswa SMK. (http://lppmp.uny.ac.id/sites/. 